\title{
2005年台風14号豪雨で発生した宮崎県槻之河内地すべりの活動履歴 \\ Movement history of Tsukinokawachi-landslide caused by heavy rainfall associate with Typhoon 0514, Miyazaki, Japan
}

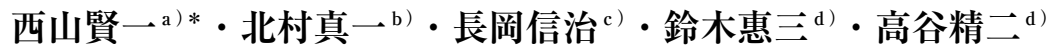 \\ Ken-ichi NISHIYAMA, Shin-ichi KITAMURA, Shinji NAGAOKA, Keizo SUZUKI and Seiji TAKAYA
}

\begin{abstract}
Many landslides and slope failures triggered by heavy rainfall associated with Typhoon 0514 occurred in Miyazaki, Japan. Tsukinokawachi-landslide is one of the huge landslides distributed in Wanitsuka Mountains formed landslide dam due to 2005 heavy rainfall. The slide block of Tsukinokawachi-landslide is overlain by several marker tephra layers such as AT (29cal ka), K$\mathrm{Ah}(7.3 \mathrm{cal} \mathrm{ka})$ and $\mathrm{Kr}-\mathrm{M}(4.6 \mathrm{cal} \mathrm{ka})$, but not by A-Fm (31 cal ka), A-Iw (45-50ka) and A-Fk (90ka). These occurrences of tephra layers suggest that former movement of Tsukinokawachi-landslide occurred between 31 and $29 \mathrm{cal} \mathrm{ka}$.

Key words : landslide, tephrochlonology, heavy rainfall disaster, Miyazaki Prefecture

\section{和文要旨}

2005年台風14号に伴う豪雨により，宮崎県では大規模な地すべりや斜面崩壊が複数発生した。鰐堷山地に位置する柣之㠰河孛で発 生した地すべりは，2005年豪雨で発生したなかでも大きいものの一つであり，地すべり移動体は河道閉塞による地すべりダムを形 成した。槻之河内地すべりの旧地すべり移動体は, AT (29cal ka), K-Ah (7.3cal ka), Kr-M (4.6cal ka) の各テフラに覆われる が，A-Fm（31cal ka)，A-Iw (45〜50ka)，A-Fk（90ka）の各テフラが欠如する。これらのテフラの産状から，2005年の 1 回前の 地すべりは31〜29cal ka間に発生した可能性がある。

キーワード：地すべり，テフロクロノロジー，豪雨災害，宮崎県
\end{abstract}

\section{1.はじめに}

日本各地に分布する地すべりには，歴史時代に継続 的・反復的な地すべり移動が生じたものも知られている が，歴史時代における活動が明暸でない地すべりも多い。 しかし，そのような地すべりも，地震や豪雨などにより 再活動して大きな被害をもたらすことがあるため，長期 的な地すべりの活動履歴を明らかにする必要がある。一 般に，歴史記録のない地すべりの活動履歴の解明は容易 ではないが，移動体や凹地に含まれる木片の ${ }^{14} \mathrm{C}$ 年代や テフラを用いた地すべりの活動履歴の検討が行われてき た（青木・高浜，1976；1977；大西ほか，1984；長谷川, 1995 ; 大塚ほか, 1998 ; 高田ほか, 2000 ; 柳田・長谷川, 2000 ; 八木ほか, 2001 ; 渡部・八木, 2003)。また, 地 すべり移動体を被覆する土層に含まれるテフラを用いた 地すべり発生年代の検討も行われている（鬼頭・岩松, 1995 ; 植木，2001；2004；2005；北村ほか，2008）。

2005年台風14号に伴う豪雨の総雨量が $1,000 \mathrm{~mm}$ 程度 という記録的雨量に達した宮崎県の山間部では，大規模 な地すべりが複数発生した（古閑ほか，2006；千木良， 2006 ; 高谷・鈴木, 2007 ; 清水, 2009)。宮崎県南部の 鰐堔山地に位置する譛灾河内では大規模な地すべりが発 生し, 地すべり移動体が河道を閉塞して地すべりダムを

* 連絡著者/corresponding author

a 徳島大学大学院ソシオアーツアンドサイエンス研究部 Institute of Socio-Arts and Sciences, Univ. Tokushima テ770-8502 徳島市南常三島町1-1

Minamijosanjima1-1, Tokushima 770-8502

b ）株式会社ニュージェック

NEWJEC In

) 長崎大学教育学部

Faculty of Education, Nagasaki Univ.

d) 南九州大学

Minamikyushu Univ.
形成する被害が出た。鰐塚山地は，霧島・姶良などのカ ルデラ火山に近いことから, 第四紀後期のテフラが多数 分布して扔り，それらの層序・年代が詳細に明らかにさ れている（長岡ほか，2001，2010; 町田・新井，2003）。 したがって，地すべり移動体を被覆するテフラに基づい て，過去数万年間にわたる地すべり活動履歷を検討する ことができ,すでに予察的な検討が行われている(鬼頭・ 岩松，1995）。今回は槻之河内地すべりを対象とし，地 すべり移動体を覆う複数のテフラに基づき，2005年以前の 地すべりの活動履歴について検討を行ったので報告する。

\section{2. 調査地域の地形・地質概要と後期更新世テフラ} 鱞塚山地（図－1）は宮崎平野の南方に位置し, 鱞塚

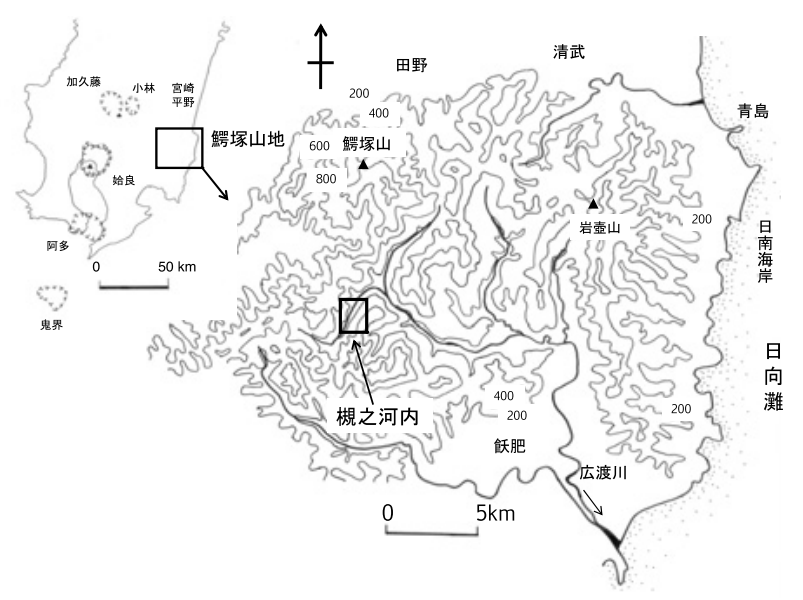

図-1 鰐塚山地周辺の地形概要と調査地域

Fig. 1 Geomorphological setting around Wanitsuka Mountains and study area 
山 $(1,119 \mathrm{~m})$ を主峰とする山地である。鰐塚山地の地 形は，全般に谷密度が低く緩斜面が多いことに加え，斜 面には多数の地すべり地形が分布する（鬼頭・岩松， 1995 ; 古閑ほか, 2006)。鰐塚山地東麓の日南海岸，な らびに北方の宮崎平野には多段化した多くの段丘が分布 する（長岡，1986；長岡ほか，1991）が，山地内には明 瞭な段丘は分布しない。

鰐塚山地を構成する基盤岩は, 四万十帯の付加コンプ レックス（古第三系日向層群・日南層群）と，それを不 整合で覆う浅海性の新第三系〜第四系宮崎層群である （木野，1958；木野·太田，1977；宮崎県，1997）。今回 の調査範囲は四万十帯の日向層群からなり，細粒〜中粒 の厚い塊状砂岩がほとんどを占め，少量の泥岩を伴う。

概ね北東一南西走向で，北西に30～ $50^{\circ}$ 程度で傾斜する ことが多い。

鰐塚山地は, 加久藤・小林, 姶良, 阿多, 鬼界といっ たカルデラ火山をつなぐ火山フロントの東側に位置して いるため, 多数の後期更新世のテフラが分布する（図 1 )。それらは，上位より，4.6 cal kaの霧島御池降下軽 石：Kr-M，7.3cal kaの鬼界アカホヤ降下火山灰：K$\mathrm{Ah}$ (基底に鬼界幸屋降下軽石：K-KyPを伴う), 29cal ka の姶良大隅降下軽石：A-Os - 姶良入戸火砕流：AIto - 姶良Tn降下火山灰：AT, 31cal kaの姶良深港降 下軽石：A-Fm, 32.5cal kaの姶良大塚降下軽石：A-Ot, 45～50kaの姶良岩戸降下軽石：A-Iw，90kaの姶良福山 降下軽石：A-Fk，95kaの鬼界葛原降下火山灰： $\mathrm{K}-\mathrm{Tz}$ などである（長岡ほか，2001，2010；奥野，2002；町 田・新井，2003。テフラのうち， Kr-M, K-Ah， AT, $\mathrm{A}-\mathrm{Fm}, \mathrm{A}-\mathrm{Ot}$ の年代值は奥野（2002）による暦年值， それ以外は町田・新井（2003）による值を用いた）。 $\mathrm{A}$ Itoは, 鰐塚山地の谷底では小規模なシラス台地を形成 するが, 山地斜面には厚い火砕流堆積物は分布しない (横 山, 2000)。

\section{3. 槻之河内地すべり地に分布するテフラの記載と対比}

2005年災害前の空中写真判読による㭇之河内周辺の地 すべり地形と，2005年に移動した地すべりとを重ねて図 - 2 に示す。1974年撮影の空中写真判読によれば，移動 体上に小規模な線状凹地を伴う地すべり地形が複数認め られる（以後，旧地すべりと呼ぶ）。旧地すべりは，標 高約 $660 \mathrm{~m}$ を冠頂とする北西方向に開いた滑落崖と, 標 高470〜 550m付近に広がる緩傾斜の地すべり移動体から 構成され，さらに複数の移動ブロックに分かれている。 一方，2005年豪雨による地すべり（以後，2005年地すべ りと呼ぶ）は，線状凹地を伴う旧地すべり移動体を含む 斜面が滑落したものである。2005年地すべりの下半分は 槻之河内川の河谷に近い山麓斜面で，旧地すべり移動体 と重複しないが，全般に緩傾斜となっている。2005年災 害後に撮影された空中写真判読に基づけば，2005年地す ベりは標高約 $520 \mathrm{~m}$ 付近を冠頂とする北西方向に開いた
滑落崖をなし，移動体は角礫主体の土塊として斜面下方 へ移動し，槻之河内川の河道を閉塞して地すべりダムを 形成した $($ 写真 -1$)$ 。滑落した土塊上には，発泡のよ い径数 $\mathrm{cm}$ の褐色の軽石が散在している。

旧地すべり移動体を構成する四万十帯の岩盤は，主に 中粒〜細粒の厚い塊状砂岩からなり，全体として角碩状 〜ブロック状に破砕され，一部はジグソークラックを呈 する。角礫状をなす原因は，地すべり変動に伴う岩盤の 破砕によると推定される。岩盤の上位はしばしば複数の テフラに覆われる。旧地すべり移動体上において，テフ ラの層序関係が明瞭に把握できる 3 箇所の露頭を特に詳 しく記載し（図 - 2 の露頭 $\mathrm{A} \sim \mathrm{C})$ ，その直近の露頭の観 察も行った。いずれの露頭でも，それぞれのテフラの間 は角碟やテフラの二次的な堆積物が混在する褐色の土層 からなる。

テフラの基底部にしばしば存在する降下軽石密集層を 避け，テフラのほぼ中部付近で試料を採取し，実体顕微

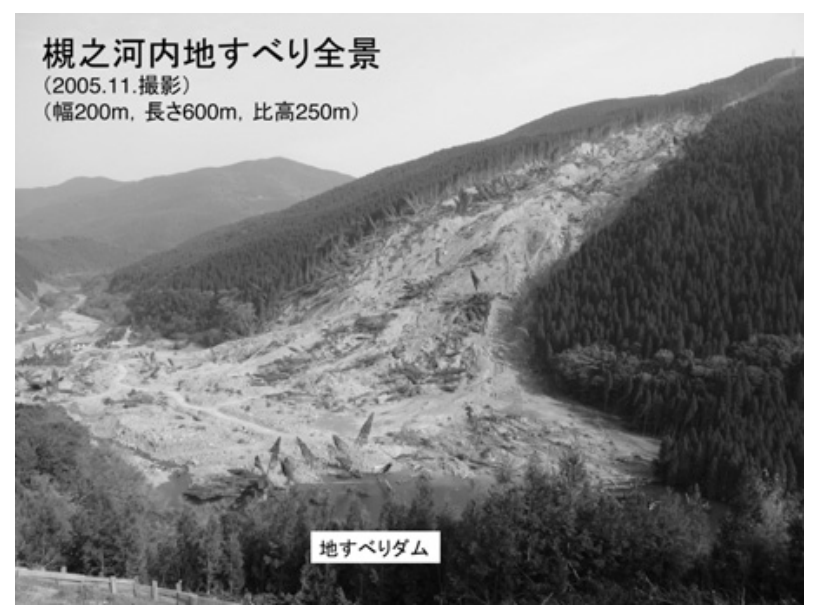

写真一 1 槻之河内地すべりの全景

Photo1 Photographic view of Tsukinokawachi-landslide

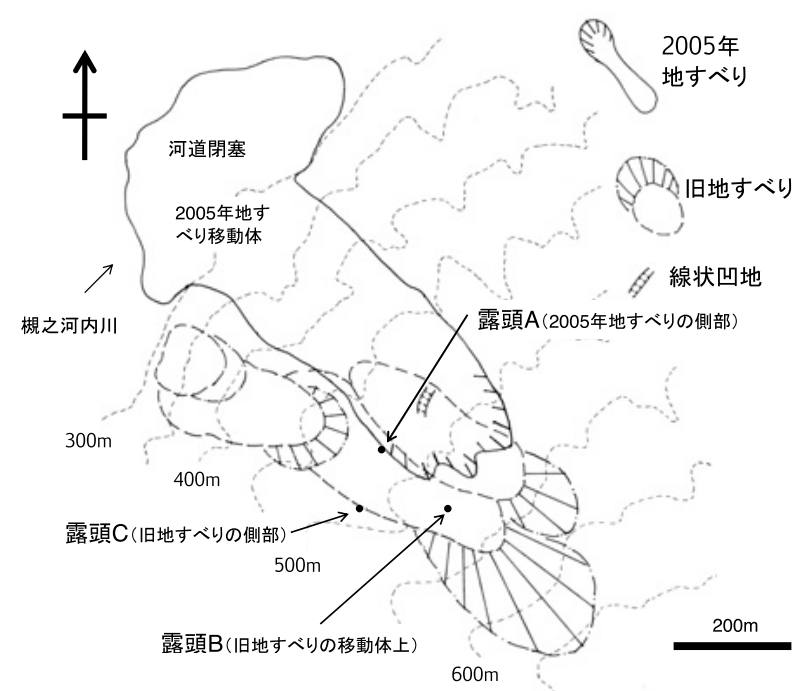

図ー2＼cjkstart槻之河内地すべりの地形判読結果

Fig. 2 Landslide geomorphology around Tsukinokawachi -landslide based on aerial photo interpretation 
鏡観察によるテフラの岩石記載的特徵の把握，および鉱 物の屈折率測定を行った。その結果を表 -1 に示す。屈 折率測定を行ったのは，火山ガラス 7 試料・斜方輝石 1 試料である。測定は株式会社古澤地質に依頼し，温度可 変型屈折率測定装置（MAIOT）を用い，火山ガラスは 30 粒子，斜方輝石は 10 粒子を，それぞれ測定した。測定 方法は古澤（1995）に従った。

2005年地すべりの上端の側部にあたる露頭A（北東向 きの林道のり面）では，旧地すべり移動体を構成する砂 岩の岩盤を覆う土層中に 3 枚のテフラが確認でき，いず れも整然と堆積している（図－3）。下位から順に，A1 ：よく発泡した径 $2 \sim 0.5 \mathrm{~cm}$ の褐色の軽石を多く含む 厚さ約 $40 \mathrm{~cm}$ の軽石質火山灰層, $\mathrm{A}-2$ ：発泡した径数 $\mathrm{mm}$ の褐色の軽石からなる厚さ約 $5 \mathrm{~cm}$ の軽石層とそれを覆 う厚さ約 $15 \mathrm{~cm}$ のガラス質火山灰層, $\mathrm{A}-3$ : 発泡の悪い 径 $5 \mathrm{~mm}$ 以下の軽石を主体とする厚さ約 $30 \mathrm{~cm}$ の細粒軽 石層, が累積する。A-1のバブルウォール型火山ガラ スの屈折率はATに一致し，発泡した軽石はAT直下のA -Osと考えられる。A-2 のバブルウォール型火山ガラス の屈折率はK-Ahに一致し，少量含まれる発泡した軽石 はK-Ah直下のK-KyPと考えられる。A-3に少量含ま れるバブルウォール型火山ガラスの屈折率はK-Ahに一 致するが，A-3 に多く含まれる発泡の悪い軽石はK-Ah およびK-KyPには対比できず，テフラ層序ならびに岩 石記載的性質から $\mathrm{Kr}-\mathrm{M}$ に対比され， $\mathrm{A}-3$ に少量含まれ るK-Ahは二次的な混入物と考えられる。

露頭Aのすぐ東側の林道路床から約 $100 \mathrm{~cm}$ 下には，角
礫状を呈する砂岩の岩盤が露出しており，砂岩とA-1 の間には砂混じり褐色土層が分布し，テフラは認められ ない。また，露頭Aの西側に連続する林道のり面には角 磁状を呈する砂岩が露出しており，砂岩の上位を，100 $\mathrm{cm}$ 程度の礫混じり褐色土層を介して, A-1 と同じ軽石 質火山灰層が被覆している。したがって，露頭A周辺で は，砂岩の上位を被覆する最下位のテフラはA-1である。 2005年地すべりよりも上方，旧地すべりの移動体上に ある露頭B（北向きの林道のり面）では，地すべり移動 体は直接露出しないが，移動体を覆う土層中に 3 枚のテ フラが確認でき，下位の 2 枚が小断層により切断されて いる（図 -4$)$ 。

テフラは，下位から順に，B-1：よく発泡した褐色 の軽石（径 $1 \sim 2 \mathrm{~cm}$ ，最大 $5 \mathrm{~cm}$ ）を多く含む厚さ約 40 $\mathrm{cm}$ の軽石質火山灰層，B-2：よく発泡した褐色の軽石

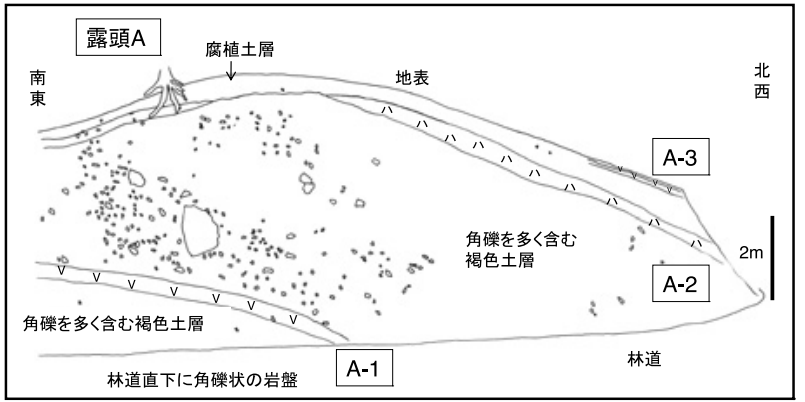

図一 3 槻之河内地すべりの移動体を覆うテフラ（露頭A）

Fig. 3 Sketch of the several marker tephra layers covers the landslide body (Locality A)

表ー 1 テフラの岩石記載的特徴および屈折率測定結果

Table 1 Petrographic properties and refractive index of tephras

\begin{tabular}{|c|c|c|c|c|c|c|}
\hline $\begin{array}{l}\text { 試料 } \\
\text { 番号 }\end{array}$ & $\begin{array}{l}\text { 厚さ } \\
(\mathrm{cm})\end{array}$ & 主要鉱物組成 & $\begin{array}{c}\text { 火山ガラスの } \\
\text { 形態と量 }\end{array}$ & $\begin{array}{c}\text { 火山ガラスの } \\
\text { 屈折率 }\end{array}$ & $\begin{array}{c}\text { 斜方輝石の } \\
\text { 屈折率 }\end{array}$ & 対比されるテフラ \\
\hline$A-1$ & 40 & $\mathrm{gl}, \mathrm{opx}, \mathrm{cpx}$ & $\mathrm{bw}=\mathrm{pm}$ & $1.496-1.5005$ & - & AT (A-Os の軽石を含む) \\
\hline$A-2$ & 20 & $\mathrm{gl}, \mathrm{opx}, \mathrm{cpx}$ & $\mathrm{bw}>\mathrm{pm}$ & $1.509-1.515$ & - & $\mathrm{K}$-Ah（基底に K-KyPを含む） \\
\hline$A-3$ & 30 & $\mathrm{gl}, \mathrm{opx}, \mathrm{cpx}$ & $\mathrm{pm} \gg>\mathrm{bw}$ & $1.509-1.514$ & - & $\mathrm{Kr}-\mathrm{M}$ （K-Ah の bw が混入） \\
\hline $\mathrm{B}-1$ & 40 & $\mathrm{gl}, \mathrm{opx}, \mathrm{cpx}$ & $\mathrm{pm}>\mathrm{bw}$ & $1.498-1.5005$ & $1.732-1.738$ & AT (A-Os の軽石を含む) \\
\hline$B-2$ & 15 & $\mathrm{gl}, \mathrm{opx}, \mathrm{cpx}$ & $\mathrm{pm}>\mathrm{bw}$ & - & - & $\mathrm{B}-1$ (AT) の二次的な堆積物 \\
\hline B-3 & 25 & $\mathrm{gl}, \mathrm{opx}, \mathrm{cpx}$ & $\mathrm{bw}>\mathrm{pm}$ & $1.510-1.520$ & - & $\mathrm{K}-\mathrm{Ah}$ （基底に K-KyPを含む） \\
\hline $\mathrm{C}-1$ & 30 & gl, opx, cpx & $\mathrm{bw}>\mathrm{pm}$ & $1.496-1.5005$ & - & AT (A-Os の軽石を含む) \\
\hline $\mathrm{C}-2$ & 20 & gl, opx, cpx & $\mathrm{bw}=\mathrm{pm}$ & $1.509-1.516$ & - & $\mathrm{K}-\mathrm{Ah}$ \\
\hline $\mathrm{C}-3$ & 10 & $\mathrm{gl}, \mathrm{opx}, \mathrm{cpx}$ & $\mathrm{pm}>>\mathrm{bw}$ & - & - & Kr-M（K-Ah の bw が混入） \\
\hline
\end{tabular}

$\mathrm{gl}$ : 火山ガラス, opx: 斜方輝石, $\mathrm{cpx}$ : 単斜輝石, bw: バブルウオール型火山ガラス, pm: パ ミス型火山ガラス (低発泡型を含む) 
（径 1 〜 $2 \mathrm{~cm}$ ，最大 $5 \mathrm{~cm}$ ）と砂岩の岩片を多く含む厚 さ約 $15 \mathrm{~cm}$ の礫混じり軽石質火山灰層, B- 3 : 発泡した 径数 $\mathrm{mm}$ の褐色の軽石からなる厚さ約 $3 \mathrm{~cm}$ の軽石層と それを覆う厚さ約 $25 \mathrm{~cm}$ のガラス質火山灰層，が累積す る。B-1のバブルウォール型火山ガラスと斜方輝石の 屈折率はATに一致し，発泡した軽石はAT直下のA-Os と考えられる。 $\mathrm{B}-3$ のバブルウォール型火山ガラスの 屈折率は $\mathrm{K}-\mathrm{Ah} に 一$ 致し，少量含まれる発泡した軽石は $\mathrm{K}-\mathrm{KyP}$ と考えられる。B-2 の試料の屈折率測定は行っ ていないが，含まれる軽石はB-1に酷似しており，径 数 $\mathrm{cm}$ 以下の砂岩礫が多く含まれ，軽石が基質中に点在 する形態を示し，軽石が密集して岩片がほとんど含まれ ないB-1 と明暸に異なる。このことから，B-2 はB-1 の二次的な堆積物と考えられる。B-1 テフラの落ち込 んだ側は露出していないが，少なくとも $40 \mathrm{~cm}$ 以上ずれ ており，B-2 テフラのずれは $70 \mathrm{~cm}$ 以上る。この小断 層に，破砕帯やテフラの引きずり構造などは認められな い。小断層により変位を受けているのはATおよびその 二次的な堆積物のみであり。それを覆う $\mathrm{K}-\mathrm{Ah}$ は変位を 受けておらず，K-Ahを含む土層が小断層による凹部を 埋積している。

露頭B周辺の林道のり面では，角礫状を呈する砂岩の 岩盤が断片的に露出しており，その上位は，厚さ約 $50 \mathrm{~cm}$ の礫混じり褐色土層を介して，B-1 と同じ軽石質火山 灰層に覆われている。したがって，露頭B周辺では，砂 岩を被覆する最下位のテフラはB-1 である。

2005年地すべりより南西に位置し，旧地すべりの南西 端付近にあたる露頭C（北向きの林道のり面）では，地 すべり移動体を覆う 3 枚のテフラが観察され，最下位の テフラが地すべり移動体とともに大きく変形している (図－5 )。ジグソークラックを呈する砂岩の地すべり移 動体に高角 $\left(\right.$ 約 $\left.70^{\circ}\right)$ の小断層が認められ，小断層より 東側の岩体が約 $3 \mathrm{~m}$ 落ち込んでいる。最下位の軽石層が, 高角の断層面に沿って約 $70^{\circ} の$ 急傾斜をなす。軽石層の

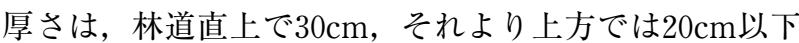
とやや薄くなり，小断層により切断されているものの，

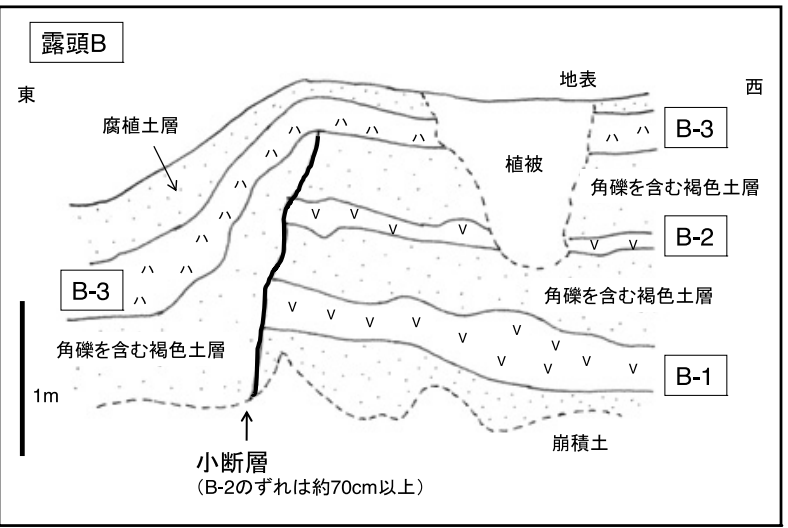

図ー4 槻之河内地すべりの移動体を覆うテフラ（露頭B）

Fig. 4 Sketch of the several marker tephra layers covers the landslide body (Locality B)
断層面より西側の岩盤の上位でも断片的に認められる。 径数 $\mathrm{cm}$ 程度の軽石を多く含む軽石層が，降下時に存在 した傾斜 $70^{\circ}$ 程度の急斜面に，厚さ $20 \sim 30 \mathrm{~cm}$ で斜面に平 行に堆積して保存されたとは考えにくいことから, 軽石 層が急傾斜した構造は堆積時のものではなく，堆積後の 変形によると考えられる。一方，この軽石層の上位に堆 積する 2 枚のテフラは，層厚もほぼ一定で変形が認めら れず，テフラを含む褐色土層が小断層沿いの凹部を埋積 している。

3 枚のテフラは下位から順に, C- $1 ：$ よく発泡した 褐色の軽石（径数 $\mathrm{cm}$ ）を多く含む厚さ約 $30 \mathrm{~cm}$ の軽石質 火山灰層, C-2 : 厚さ約 $20 \mathrm{~cm}$ のガラス質火山灰層, $\mathrm{C}-$ 3 ：発泡の悪い径 $5 \mathrm{~mm}$ 以下の軽石を主体とする厚さ約 $10 \mathrm{~cm}$ の軽石層，が累積する。C-1 のバブルウォール型 火山ガラスの屈折率はATに一致し，発泡した軽石はAT 直下のA-Osと考えられる。C-2 のバブルウォール型火 山ガラスの屈折率は $\mathrm{K}-\mathrm{Ah} に 一$ 致する。C -3 に多く含ま れる発泡の悪い軽石は $\mathrm{Kr}-\mathrm{M}$, 少量含まれるバブル ウォール型火山ガラスの屈折率は $\mathrm{K}-\mathrm{Ah} に 一$ 致するため, その二次的な混入物と考えられる。したがって，小断層 付近で最大 $70^{\circ}$ で急傾斜するテフラはATであり，それ を覆う $\mathrm{K}-\mathrm{Ah} ， \mathrm{Kr}-\mathrm{M}$ 変位は認められない。

\section{4. 指標テフラに基づく槻之河内地すべりの活動履歴}

地すべり移動体を被覆するテフラに基づいて，地すべ

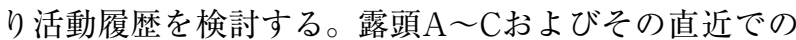
観察結果と屈折率測定結果から，四万十帯の岩盤を被覆 するテフラは，下位からAT（A-Osを含む)，K-Ah（K -KyPを含む)，Kr-Mの 3 枚である。露頭 $\mathrm{B} て ゙$ 観察され る小断層は，断層破砕帯を伴わず，断層に沿ったテフラ の引きずりなども認められないことから，ノンテクト ニックな成因，すなわち地すべり移動体の変形によるク ラックを考えるのが妥当であろう。露頭Bで変形してい るのはATおよびその二次的堆積物であり，被覆するKAhには変形は認められない。したがって，露頭B付近

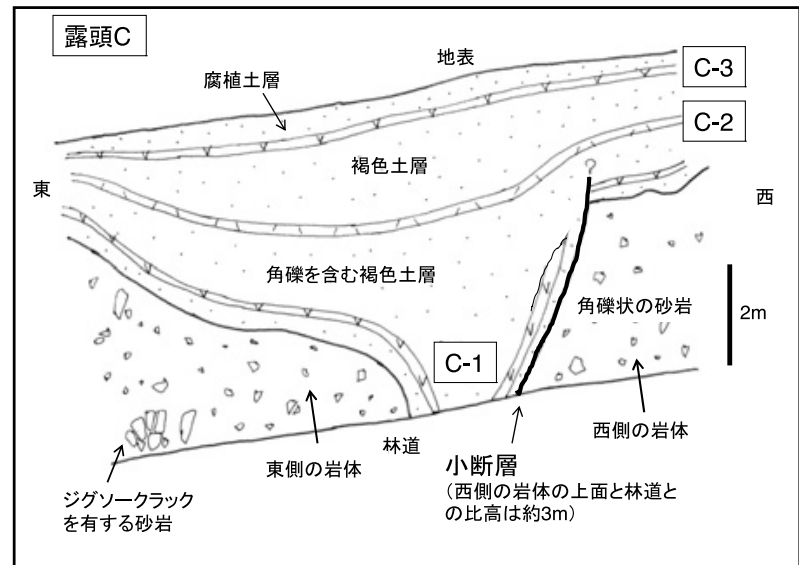

図ー 5 槻之河内地すべりの移動体を覆うテフラ（露頭C）

Fig. 5 Sketch of the several marker tephra layers covers the landslide body (Locality C) 
の旧地すべり移動体では, AT降下後〜 K-Ah降下前に, $\mathrm{AT}$ 二次的な堆積物を見かけの落差 $70 \mathrm{~cm}$ 以変位させ る変形が生じたと考えられる。空中写真判読では, 露頭 B付近に凹地や崖は判読できないため, 上記の小断層は 旧地すべりの滑落崖ではなく，旧地すべり移動体の変形 によって生じたクラックと考えられる。

露頭C付近の砂岩の岩盤は著しく角磁質であり，ジグ ソークラックが認められること, 空中写真判読でも旧地 すべりの移動体の側部にあたる (図-2）ことから，こ の岩盤は地すべり移動体と考えられる。岩盤を覆うテフ ラのうち，大きく変形しているものはATのみであり， その上位の $\mathrm{K}-\mathrm{Ah}$ と $\mathrm{Kr}-\mathrm{M} に は$ 変形が認められないこと から, 露頭Cを含む旧地すべりの南西端では, AT降下 後〜 K-Ah降下前に, 見かけの落差約 $3 \mathrm{~m}$ の変形が発生 したと考えられる。露頭Cの小断層より東側にあたる旧 地すべり移動体側が約 $3 \mathrm{~m}$ 落ち込んだ形態をなすことか ら，この小断層は旧地すべり移動体の側部に生じたク ラックと考えられる。

露頭 $\mathrm{A} \sim \mathrm{C}$ は，槻之河内地すべりの旧移動体上に位置 し, AT以降のテフラに覆われることから, 旧地すべり の発生はATの降下（29cal ka）前である。また, ATの 降下後〜 K-Ahの降下前（29～7.3cal ka間）に少なくと も 1 回, 旧地すべり移動体の上部および南西端で, 移動 体を被覆するテフラを変位させる土塊の変形が発生した と考えられる。一方，K-Ah降下後には，これらのテフ ラを変位させるような旧地すべり移動体の変形が生じて いない。2005年には, 旧地すべり移動体を一部含む斜面 が滑動し，河道閉塞による地すべりダムを形成した。

2005年に滑落した地すべり移動体の土塊上には, 径数 $\mathrm{cm}$ のよく発泡した褐色の軽石が散在しており，この特 徵はAT直下のA-Osに酷似する。2005年地すべり移動 体（写真－1）は著しく乱された角磁主体の土塊である ためテフラ層序が明確ではないが，2005年に地すべりが 発生した斜面には, 少なくとも A-Osを含むAT以降の テフラが累積していたと考えられる。一方, 露頭 $\mathrm{A} \sim \mathrm{C}$ およびその直近には, 鰐塚山地に $20 \mathrm{~cm}$ 以上の厚さで分 布する29cal ka以前のテフラ (31cal kaのA-Fm, 50〜 45kaのA-Iw，90kaのA-Fkなど）が残存していない。 $\mathrm{A}-\mathrm{Fm}$ 以前のテフラが現在のところ確認されないことか ら, 旧地すべりの発生時期は, AT降下前〜 A-Fm降下 後（31〜 29cal ka間）の可能性がある。ただし, ATよ り古いテフラが地すべり移動体上に残存する可能性も否 定できないため, 旧地すべり移動体上，および移動体直 近斜面上の詳細なテフラ層序の解明が, 地すべり発生時 期を特定するために必要である。

今回の検討結果は, 最終水期に発生した地すべりが多 いという鰐塚山地南部の地すべりの編年結果（鬼頭・岩 松，1995）とも調和的である。日本各地の地すべりの編 年結果（長谷川, 1995 ; 大塚ほか, 1998 ; 植木, 2001 ; $2004 ; 2005$; 八木ほか, 2001 ; 渡部・八木, 2003 ; 北村
ほか，2008）では，大規模な地すべりは最終氷期後半〜 完新世に発生したものが多いとされ，最終水期から完新 世にかけての気候変化と, それに伴う降水量や侵食基準 面の変化などが地すべりの発生に関与すると考えられて いる。

今回の検討は, 九州南部の鰐塚山地に分布する 1 つの 地すべりのみに限定された議論であり，90kaのA-Fkに 覆われる古期の地すべりが存在するとともに，AT降下 以降に地すべり活動が活発化したという見解（鬼頭・岩 松，1995）や，最終水期以降の地すべり活動の活発化に 関する検討は行えなかった。また，斜面に残存するテフ ラを用いた編年の試みが，東北・北海道でいくつか報告 されている（清水ほか, 1995 ; 吉永・小岩, 1996など） ものの, 豪雨常襲地域である九州南部での検討は少なく, 今回検討した槻之河内地すべり地内外の斜面の編年も十 分ではない。そのため，2005年に鰐塚山地で発生したこ のほかの地すべりについても，地すべり地内外の斜面を 被覆するテフラの同定に基づく編年を行う必要がある。

\section{5. まとめ}

2005年台風14号豪雨で発生した宮崎県鰐塚山地の槻之 河内地すべりにおいて，2005年災害以前の旧地すべり移 動体を被覆するテフラを同定し，地すべりの活動履歴に ついて検討した。テフラ層序・岩石記載的特徵・屈折率 測定結果に基づけば，旧地すべり移動体を被覆するテフ ラは，下位から AT, K-Ah，Kr-Mの 3 枚であり，旧地 すべりの発生はATの降下（29cal ka）前である。地す ベり移動体を覆うテフラは整然と堆積する場所もあるが, ATのみ変形を受け，それを覆う $\mathrm{K}-\mathrm{Ah}, \mathrm{Kr}-\mathrm{M} に は$ 変形 が認められない場所がある。このことから，AT降下後 〜 K-Ah降下前（29〜 7.3cal ka間）に，テフラを最大で 数 $\mathrm{m}$ 程度変位させる旧地すべり移動体の変形が生じたと 推定される。一方， $\mathrm{K}-\mathrm{Ah}$ 降下後には，これらのテフラ を変位させる旧地すべり移動体の変形が生じていない。 2005年豪雨では，この旧地すべり移動体の一部を含む斜 面が移動し, 河道閉塞による地すべりダムが形成された。 なお，鰐塚山地は，AT降下前のテフラであるA-Fm， $\mathrm{A}-\mathrm{Iw}, \mathrm{A}-\mathrm{Fk}$ など複数のテフラの分布範囲に含まれる が，槻之河内地すべりの旧移動体上の 3 露頭およびその 直近では確認されなかった。このことから，旧地すべり の発生はAT降下前〜 A-Fm降下後（31～29cal ka間）の 可能性がある。

\section{謝辞}

国際航業株式会社の古閑美津久氏には，2005年災害後 に撮影された空中写真を閲覧させていただいた。査読者 の指摘により本稿は改善された。以上の方々に, 記して 感謝申し上げる。 


\section{参考文献}

青木 滋・高浜信行（1976）：地すべり地の履歴に関する研究（そ の 1). 新潟大学地盤災害研究施設年報, No. 2, pp. 11-18.

青木 滋・高浜信行（1977）：新潟県における初生斜面崩壊の発生 期と発生原因に関する一考察－地すべり地の履歴に関する研 究 (その 2 ) -. 新潟大学地盤災害研究施設年報, No. 3, pp. 19 $-29$.

千木良雅弘（2006）：2005年台風14号による九州の土砂災害．京都 大学防災研究所年報, No. 49A, pp. 23-34.

長谷川修一（1995）：大規模地すべり地形の形成年代からみた四国 島の地すべり発達史. 日本地すべり学会関西支部シンポジウ 厶「大規模地すべり・崩壊の事例解析」, pp. 35-49.

古澤 明 (1995)：火山ガラスの屈折率測定・形態分類とその統計 的な解析. 地質学雑誌, Vol.101-2, pp. 123-133.

木野義人（1958）：日向青島地域の地質（5万分の 1 地質図幅）, 地質調査所, 63p.

木野義人・太田良平（1977）：都城地域の地質（5 万分の 1 地質図 幅)，地質調查所，45p.

北村真一・西山賢一・川村教一（2008）：テフロクロノロジーによ る徳島県神山町の高根地すべり, 東大久保地すべりの発生時 期の推定. 徳島大学総合科学部自然科学研究, No. 22, pp. 1 $-11$.

鬼頭伸治・岩松睴（1995）：テフラを用いた南九州日向帯における 地すべりの発生年代区分. 日本応用地質学会平成 8 年度研究 発表会講演論文集, pp. $233-236$.

古䦥美津久 · 堀川毅信 - 宇城 輝 - 谷内正博 (2006)：2005年台風 14号による宮崎県鰐塚山北麓および北郷町広渡川上流の崩 壊・土石流. 応用地質, Vol. $47-4$, pp. 232-241.

町田 洋・新井房夫（2003）：新編火山灰アトラスー日本列島とそ の周辺一. 336p. 東京大学出版会.

宮崎県（1997）：20万分の 1 宮崎県地質図（第 5 版，村田明広編）. 長岡信治（1986）：後期更新世における宮崎平野の地形発達. 第四 紀研究, Vol. 25-3, pp. 139-163.

長岡信治・前圭英明・松島義章（1991）：宮崎平野の完新世地形発 達史. 第四紀研究, Vol. 30-2, pp. 59-78.

長岡信治・奥野 充・新井房夫 $(2001) ： 10$ 万 3 万年前の姶良力 ルデラ火山のテフラ層序と噴火史．地質学雑誌，Vol. 107-7, pp. $432-450$.

長岡信治・新井房夫・檀原 徹 (2010) : 宮崎平野に分布するテフ ラから推定される過去60万年間の霧島火山の爆発的噴火史. 地学雑誌, Vol.119-1, pp.121-152.

奥野 充 (2002) : 南九州に分布する最近約 3 万年間のテフラの年
代学的研究. 第四紀研究, Vol. 41-4, pp. 225-236.

大西吉一・寺川俊浩・西田彰一（1984）： ${ }^{14} \mathrm{C}$ 測定值からの地す心゙ り多発期について. 第23回地すべり学会研究発表会講演集, pp. $64-67$.

大塚富男 - 高浜信行 - 中里裕臣 - 野村 哲 - 足立照久 (1998）： 現在活動中の巨大地すべり - 群馬県烏川中流域の湯殿山巨大 地すべりの事例 - . 地球科学, Vol. 52, pp. 210-224.

清水 収 (2009)：大規模土砂災害の発生履歴と土砂移動規模の評 価 - 宮崎県の多雨地域の例 - . 砂防学会誌, Vol. 61-6, pp. 36 -42 .

清水 収 - 長山孝彦・斎藤正美 (1995) : 北海道日高地方の山地小 流域における過去8000年間の崩壊発生域と崩壊発生頻度. 地 形, Vol. $16-2$, pp. $115-133$.

高田将志・檜垣大助・柳田 誠 $(2000)$ ：地すべりの年代測定. 第 39 回地すべり学会研究発表会講演集, pp. 599-602.

高谷精二・鈴木惠三（2007）：2005年台風14号による宮崎県内に発 生した巨大崩壊. 日本地すべり学会誌, Vol.44-2, pp. 2026.

植木岳雪 (2001)：長野県北部八坂村相川周辺の地すべり地形の形 成時期：大規模な尾根移動型地すべりの発生とそのテクト ニックな意義. 第四紀研究，Vol.40-5，pp. 393-402.

植木岳雪 (2004)：長野県北部，切久保地すべりの後期更新世以降 の活動履歴. 日本地すべり学会誌, Vol.41-2, pp. 66-69.

植木岳雪（2005）：テフロクロノロジーによる徳島県西部，中内地 すべりの発生時期の推定. 日本地すべり学会誌, Vol. $42-3$, pp. $19-23$.

渡部寿郎・八木浩司 (2003)：白神山地東部・湯ノ沢川上流域にお けるテフロクロノロジーからみた最終水期以降の地すべり地 形発達. 季刊地理学, Vol. 55, pp. 122-131.

八木浩司 ·牧田 肇・斎藤宗勝 -八木令子 (2001)：青森県 · 白神 山地追良瀬川左岸中ノ沢すべりの形成年代－地すべり凹地堆 積物の放射性炭素年代とテフラー。日本地すべり学会誌, Vol. $38-2$, pp. $41-43$.

柳田 誠・長谷川修一（2000）：地すべり地形の年齢－地すべり地 形の形成から消失するまでの時間. 第39回地すべり学会研究 発表会講演集，pp. 591-594.

横山勝三（2000）：シラス学－九州南部の巨大火砕流堆積物 - . 古今書院, $177 \mathrm{p}$.

吉永秀一郎・小岩直人（1996）：森林山地に抢ける更新世末期から 完新世初頭にかけての斜面変化. 地形, Vol. $17-4$, pp. 285 -307 .

(原稿受付2009年 7 月 8 日，原稿受理2010年 7 月 9 日) 